\title{
Meningkatkan Pemahaman Siswa Kelas 5 Menggunakan Media Benda Konkret Materi Organ Pernapasan Manusia
}

\author{
Resmi Aji Hestiningrum \\ Universitas Sebelas Maret \\ resmiajihestiningrum88@gmail.com
}

\section{Article History}

accepted 01/11/2020 approved 08/11/2020 published 15/11/2020

\begin{abstract}
Through class action research conducted in each cycle discusses the use of concrete object learning media in IPA learning. The subject of this study is grade 5 students of Cimohong State Elementary School 01 Bulakamba Sub-District which numbered 34 students The purpose of this research is to improve students' understanding of respiratory system materials in humans. The data collection technique used is to compile the entire data that has been obtained in the study namely the observation sheet and evaluation sheet of students consisting of 10 items about multiple choice. The findings after conducting research and data processing then the results of the study can be described as follows: Student learning results are measured through the question of evaluation after the implementation of the study is completed in each cycle. Students' initial grades before Action showed an average score of 68.82 which is still below the specified KKM of 70 . In Action Cycle 1 shows an average value of 73.53 and in cycle 279.12 . The form of learning using concrete object media will further improve students' understanding.
\end{abstract}

Keyword: Action Research, Elementary Schol, student,

\begin{abstract}
Abstrak
Melalui penelitian Tindakan kelas yang dilaksanakan pada setiap siklus membahas tentang penggunaan media pembelajaran benda konkret dalam pembelajaran IPA. Subjek penelitian ini adalah siswa kelas 5 SD Negeri Cimohong 01 Kecamatan Bulakamba yang berjumlah 34 siswa Tujuan penelitian ini untuk meningkatkan pemahaman siswa tentang materi sistem pernapasan pada manusia. Adapun Teknik pengumpulan data yang digunakan adalah Menyusun keseluruhan data yang telah diperoleh dalam penelitian yaitu lembar observasi dan lembar evaluasi siswa yang terdiri dari 10 butir soal pilihan ganda. Temuan setelah melakukan penelitian dan pengolahan data maka hasil penelitian dapat diuraikan sebagai berikut: Hasil belajar siswa diukur melalui soal evaluasi setelah pelaksanaan pembelajaran selesai pada setiap siklusnya. Nilai awal siswa sebelum Tindakan menunjukan nilai rata-rata 68,82 yang masih dibawah KKM yang telah ditentukan yaitu 70. Pada Tindakan siklus 1 menunjukan nilai rata-rata 73,53 dan pada siklus 2 79,12 . Bentuk pembelajaran dengan menggunakan media benda konkret akan lebih meningkatkan pemahaman siswa.
\end{abstract}

Kata Kunci: Penelitian Tindakan, Sekolah Dasar, Siswa

Social, Humanities, and Education Studies (SHEs): Conference Series p-ISSN 2620-9284 https://jurnal.uns.ac.id/shes

e-ISSN 2620-9292 


\section{PENDAHULUAN}

Pendidikan adalah usaha sadar dan terencana untuk mewujudkan suasana belajar dan proses pembelajaran agar peserta didik secara aktif mengembangkan potensi dirinya untuk memiliki kekuatan spiritual keagamaan, pengendalian diri, kepribadian, kecerdasan, akhlak mulia serta keterampilan yang diperlukan dirinya, masyarakat, bangsa dan Negara.

Di dalam dunia pendidikan, terdapat banyak cabang ilmu pengetahuan salah satunya yaitu IImu Pengetahuan Alam (IPA). IImu Pengetahuan Alam atau biasa disebut IPA merupakan dasar ilmu yang melahirkan teknologi modern yang mempelajari tentang gejala alam dan kebendaan yang terjadi di sekitar kita yang tersusun secara teratur serta cara pemecahan masalahnya berdasarkan hasil observasi maupun eksperimen. IImu Pengetahuan Alam (IPA) juga termasuk salah satu mata pelajaran yang sudah dipelajari pada jenjang Sekolah Dasar. Pendidikan IPA di sekolah dasar sendiri pada hakikatnya bertujuan agar siswa menguasai pengetahuan dan fakta tentang alam sekitar berdasarkan kehidupan sehari-hari. Pendidikan IPA juga menekankan pada pengalaman siswa secara langsung untuk mencari tahu permasalahan yang ada di sekitar serta cara pemecahan masalahnya, sehingga siswa mampu menjelajahi dan memahami alam sekitar secara ilmiah. Hal ini dibuktikan dari hasil ulangan harian maupun ulangan semester yang diperoleh siswa sebagian besar nilainya di bawah KKM (Kriteria Ketentuan Minimal).

Kemampuan pemahaman sangatlah penting dalam proses pembelajaran. Akan tetapi, berdasarkan fakta di lapangan masih banyak siswa yang kurang memahami penjelasan guru. Ada siswa yang nilainya selalu renda,bahkan ada siswa yang tidak bisa mengerjakan soal atau jika mengerjakan soal pun jawaban tidak sesuai seharusnya. Berdasarkan penelitian yang dilakukan di sekolah, hasil pembelajaran IImu Pengetahuan Alam (IPA) kelas V SD Negeri Cimohong 01 masih rendah, yaitu 30\% siswa mendapatkan nilai di atas KKM, 20\% siswa mendapatkan nilai sama dengan KKM dan $50 \%$ siswa mendapatkan nilai dibawah KKM.

Pemahaman menurut Sadiman adalah suatu kemampuan seseorang dalam mengartikan, menafsirkan, menerjemahkan atau menyatakan sesuatu dengan caranya sendiri tentang pengetahuan yang pernah. Seorang siswa dapat dikatakan paham jika mampu memberikan uraian dan penjelasan lebih kreatif, tidak hanya memberikan gambaran dalam satu contoh saja, melainkan lebih luas dan baru sesuai dengan kondisi saat ini.

Kesulitan yang dialami siswa pada materi sistem pernapasan yaitu karena siswa kurang memahami bagaimana proses terjadinya pernapasan. Siswa hanya belajar melalui buku paket (tekstual) dan penjelasan dari guru. Pada materi sistem pernapasan manusia terdapat proses pernapasan, yakni proses pernapasan dada dan pernapasan perut, sehingga mereka sulit memahami bagaimana proses pernapasan itu terjadi. Selain itu, siswa juga kurang mampu menghafal organ-organ pernapasan manusia secara urut. Rendahnya pemahaman siswa mendorong guru harus untuk selalu mengadakan perbaikan secara terus menerus dalam pembelajarannya, agar masalah-masalah kesulitan belajar siswa dapat diatasi, sehingga hasil belajar siswa mencapai tujuan yang diharapkan. Masalah-masalah yang dialami oleh siswa dalam pembelajaran tidak muncul begitu saja, tetapi ada faktor-faktor penyebabnya. Hal ini mungkin karena penjelasan guru tidak disertai media / alat peraga atau media/alat peraga kurang atau bahkan tidak sesuai.

Ada beberapa hal yang penting diperhatikan dalam pembelajaran IPA yaitu tersedianya sarana dan prasarana berupa ruang laboratorium dan alat praktek (alat peraga) yang sesuai. Kegiatan pembelajaran dengan menggunakan alat peraga adalah 
wujud perpaduan konsep yang asbtrak dengan dunia nyata sehingga Nampak korelasi antara apa yang dipelajari siswa dari teori dan prakteknya.

Alat peraga didefiniskan sebagai alat bantu untuk mendidik atau mengajar supaya konsep yang diajarkan guru mudah dimengerti oleh siswa dan menjadi alat bantu dalam proses pembelajaran yang dibuat oleh guru atau siswa dari bahan sederhana yang mudah didapat dari lingkungan sekitar. Aalat ini berfungsi untuk membantu dan mempermudah dalam mencapai kompetensi pembelajaran.

Ditinjau dari perkembangan kognitif, anak-anak tingkat Sekolah Dasar memasuki tahap operasional konkret, dimana mereka belajar berdasarkan pengalaman yang telah dialaminya. Bagi anak usia sekolah dasar, penjelasan guru akan lebih dipahami jika mereka terlibat langsung di dalam pembelajaran. Pada usia Sekolah Dasar, karakteristik siswa akan cenderung menyukai pembelajaran yang memungkinkan adanya unsur permainan, begerak/berpindah tempat, bekerja dalam kelompok, dan merasakan/melakukan/memperagakan sesuatu secara langsung. Dengan demikian, sebagai guru hendaknya merancang pembelajaran dimana siswa terlibat di dalam pembelajaran tersebut, sehingga pembelajaran lebih bermakna dan menumbuhkan keaktifan pada siswa Tujuan Peneltian adalah Meningkatkan pemahaman siswa tentang materi organ pernapasan pada manusia siswa di kelas V SD Negeri Cimohong 01 Kecamatan Bulakamba Kabupaten Brebes. Manfaat Penelitian Hasil penelitian ini diharapkan dapat memberikan kontribusi yang berarti seperti Bagi guru Meningkatnya kualitas pembelajaran dikelas, sehingga pemahaman tentang materi organ pernapasan pada manusia dapat dikuasai dengan baik. Meningkatnya keterampilan guru dalam penggunaan media atau alat peraga edukatif. Bagi siswa Meningkatnya pemahaman siswa tentang materi organ pernapasan pada manusia, sehingga proses dan hasil belajar siswa meningkat.

\section{METODE}

Penelitian ini merupakan penelitian Tindakan kelas yang dilaksanakan dalam dua siklus. Setiap siklus terdiri dari tahap perencanaan, pelaksanaan, observasi dan refleksi. Subyek penelitian Penelitian dilakukan di SD Negeri Cimohong 01 Kecamatan Bulakamba Kabupaten Brebes di kelas V materi Ipa sistem pernapasan manusia pada semester I tahun pelajaran 2020-2021 dengan jumlah siswa sebanyak 34 orang, yakni terdiri dari 19 orang laki-laki dan 15 orang perempuan. Tempat dan waktu penelitian waktu penelitian ini dirumuskan pada bulan Oktober Tahun 2020 dengan jadwal berikut :

Tabel 1. Jadwal

\begin{tabular}{ll}
\hline Kegiatan & Waktu Pelaksanaan \\
\hline Prasiklus & Kamis, 1 Oktober 2020. \\
Siklus 1 & Kamis, 22 Oktober 2020 \\
Siklus 2 & Kamis, 29 Oktober 2020 \\
\hline
\end{tabular}

Indikator keberhasilan penelitian ini yaitu : sekurang-kurangnya $75 \%$ siswa kelas V SD Negeri Cimohong 01 dapat meningkat prestasinya dalam pembelajaran matematika materi ipa sistem pernapasan manusia sesuai standar KKM yang ditentukan yaitu 70. Kategori hasil penilaian secara keseluruhan meliputi : sangat baik (85-100), baik (74-84), cukup (60-74),kurang (0-59). 


\section{Pra Siklus}

\section{HASIL DAN PEMBAHASAN}

Dari hasil nilai rapor matematika semester I dapat diketahui 10 orang siswa kategori tinggi, 10 siswa kategori sedang dan 14 orang siswa kategori rendah. Dengan ketuntasan hasil belajar sebanyak 20 siswa (58,82\%) dan yang belum tuntas 14 siswa $(42,18 \%)$.

\section{Siklus 1}

Setelah dilaksanakan perbaikan pembelajaran pada siklus 1, jumlah siswa yang tuntas dalam belajar menjadi 27 siswa $(79,41 \%)$ dengan nilai rata-rata 73,53. Ini berarti ada kenaikan ketuntasan belajar sebesar 20,59\% dan kenaikan nilai rata-rata kelas 5 dari studi awal. Pada Siklus 1 siswa yang benar-benar menunjukan keaktfian belajar 20 siswa atau 58,82\% dan sikap dalam mengerjakan tugas tepat waktu 25 siswa atau $75.53 \%$.

Perubahan penggunaan metode pembelajaran ceramah ke media pembelajaran benda konkret mampu meningkatkan pemahaman materi. Berdasarkan hasil analisis dan refleksi pertama ternyata ketuntasan belajar belum mencapai pada batas yang ditetapkan dari 34 siswa yang mencapai ketuntasan 25 siswa.

Berdasarkan hasil diskusi dengan observer diketahui gejala paling umum terjadi pada siswa yang belum tuntas karena mereka kesulitan memahami materi sistem pernapasan pada manusia. Hal ini terjadi karena siswa belum terbiasa dengan istilah yang ada pada materi tersebut. Upaya yang dilakukan untuk mengantisipasi keadaan tersebut pada siklus ke 2 dengan memberi pengertian kepada siswa tentang istilah pada sistem pernapasan menggunakan bahasa yang mudah dipahami dan penggunaan media benda konkret.

\section{Siklus 2}

Setelah dilaksanakan perbaikan pembelajaran pada siklus 2, jumlah siswa yang tuntas dalam belajar menjadi 32 siswa $(94,12 \%)$ dengan nilai rata-rata 79,12 . Ini berarti ada kenaikan ketuntasan belajar sebesar $14,71 \%$ dan kenaikan nilai rata-rata kelas 5 dari studi awal. Pada Siklus 2 siswa yang benar-benar menunjukan keaktfian belajar 25 siswa atau 75,53\% dan sikap dalam mengerjakan tugas tepat waktu 27 siswa atau 79,41\% .

Perubahan penggunaan metode pembelajaran ceramah ke media pembelajaran benda konkret mampu meningkatkan pemahaman materi. Berdasarkan hasil analisis dan refleksi pertama ternyata ketuntasan belajar belum mencapai pada batas yang ditetapkan dari 34 siswa yang mencapai ketuntasan 32 siswa.

Berdasarkan hasil diskusi dengan observer diketahui 2 siswa belum tuntas karena mereka kesulitan memahami materi sistem pernapasan pada manusia dan kemampuan membaca. Upaya yang akan dilakukan dengan memberikan pelajaran khusus membaca, sehingga dapat membaca dengan lancar dan dapat memahami isi sebuah bacaan. 


\section{PEMBAHASAN}

Setelah dilakukan analisis terhadap data diatas diketahui tingkat pemahaman siswa terhadap materi sistem pernapasan pada manusia menunjukan kenaikan angka pemahaman dan ketuntasan belajar yang siginifikan hal ini dapat dilihat pada tabel rekapitulasi ketuntasan belajar siswa pada setiap siklus

Tabel 2. Rekapitulasi Ketuntasan Belajar Siswa pada Setiap Siklus.

\begin{tabular}{|c|c|c|c|c|c|c|}
\hline \multirow[t]{2}{*}{ No. } & \multirow[t]{2}{*}{ Pembelajaran } & \multicolumn{5}{|c|}{ Hasil Belajar Siswa } \\
\hline & & $\begin{array}{l}\text { Nilai rata- } \\
\text { rata kelas }\end{array}$ & Tuntas & Persentase & Belum & Persentase \\
\hline 1. & Pra Siklus & 68,82 & 20 & $58,82 \%$ & 14 & $41,18 \%$ \\
\hline 2. & Siklus 1 & 73,53 & 27 & $79,41 \%$ & 7 & $20,59 \%$ \\
\hline 3. & Siklus 2 & 79,12 & 32 & $94,12 \%$ & 2 & $5,88 \%$ \\
\hline
\end{tabular}

Dari tabel tersebut diperoleh keterangan sebagai berikut :

1.Pada kondisi awal siswa yang sudah mencapai angka ketuntasan belajar 58,82\%.

2.Pada Siklus 1 angka ketuntasan siswa naik menjadi $79,41 \%$.

3.Pada Siklus 2 angka ketuntasan siswa naik menjadi $94,12 \%$.

4.Pada Pra Siklus nilai rata-rata kelas mencapai 68,82

5.Pada Siklus 1 , nilai rata-rata kelas mencapai 73,53 yang berarti mengalami kenaikan sebanyak 20,59\% dari Pra Siklus.

6. Pada Siklus 2, nilai rata-rata kelas mencapai 79,12 yang berarti mengalami kenaikan sebanyak $14,71 \%$ dari siklus 1 .

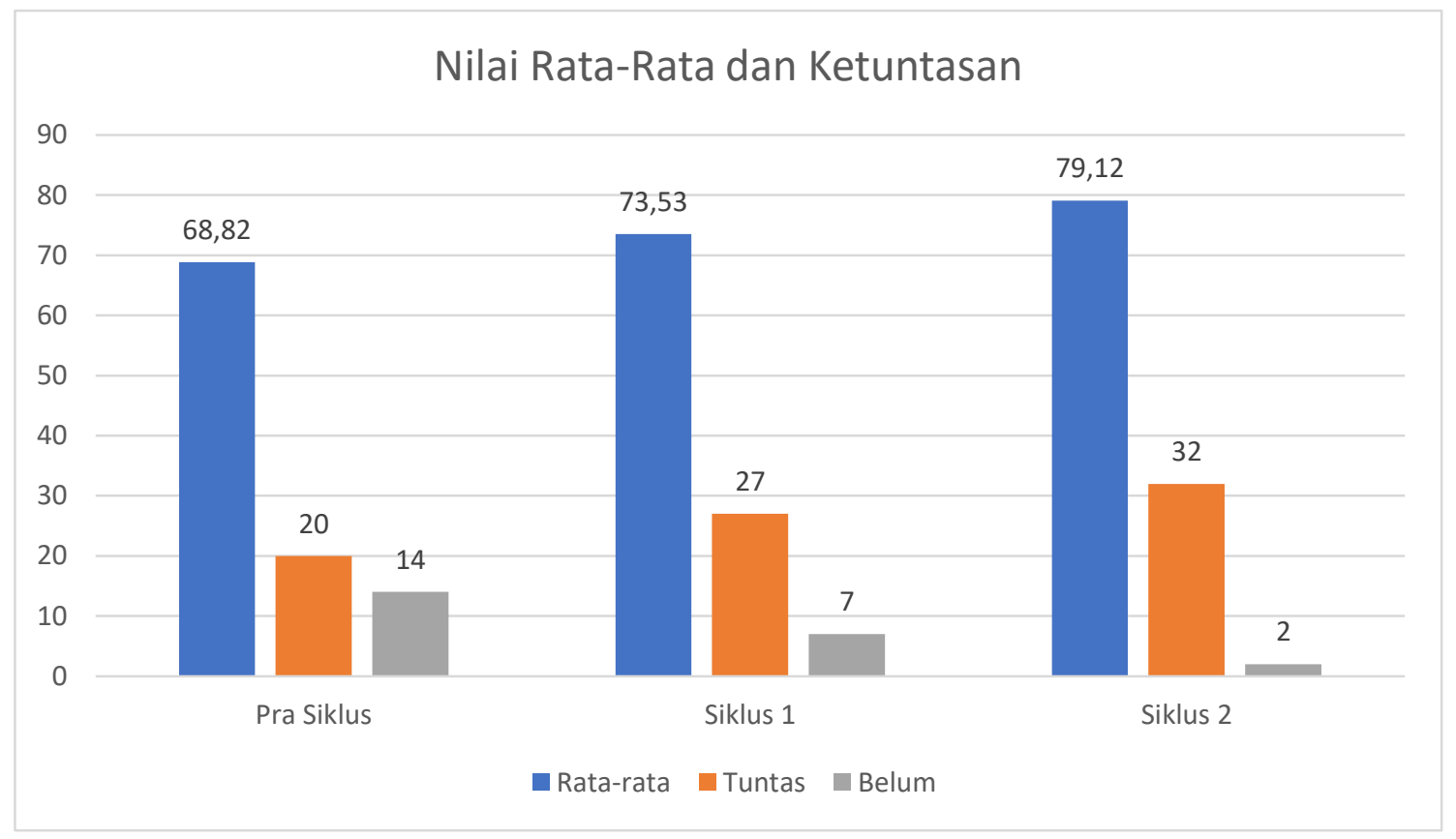

Gambar 1. Rata-Rata Kelulusan 


\section{SIMPULAN}

Berdasarkan temuan dan analisis yang diperoleh dalam pelaksanaan tindakan perbaikan pembelajaran IImu Pengetahuan Alam tentang materi Sistem Pernapasan pada Manusia dengan menggunakan media pembelajaran benda konkret dari setiap siklus dapat disimpulkan sebagai berikut : (1) Pemahaman siswa terhadap materi sistem pernapasan dengan menggunakan media benda konkret dapat meningkat. Hal itu dapat dilihat dari hasil yang diperoleh siswa dalam pembelajaran sistem pernapasan manusia ada peningkatan. (2) Media pembelajaran benda konkret dapat meningkatkan prestasi belajar siswa kelas 5 SD Negeri Cimohong 01 terhadap mata pelajaran IPA tentang sistem pernapasan pada manusia terbukti dari: Pada siklus 1 nilai rata-rata siswa meningkat menjadi 73,53 dengan persentase ketuntasan $79,41 \%$. Pada Siklus 2 nilai ratarata siswa meningkat menjadi 79,12 dengan persentase $94,12 \%$.

\section{DAFTAR PUSTAKA}

Arikunto,S. 2014 . Penelitian tindakan kelas. Jakarta: Bumi Aksara.

Kusumah, Wijaya dan Dedi Dwitagama.2011. Mengenal Penelitian Tindakan Kelas. Edisi : 2. Jakarta: PT Indeks.

Susanto,Ahmad, 2013. Teori Belajar dan Pembelajaran di Sekolah Dasar.Jakarta: Kencana.

Widyatmoko,A dkk,2012. "Pembelajaran Berbasis Proyek Untuk mengembangkan Alat Peraga IPA dengan Memanfaatkan Bahan Bekas Pakal". Laporan Penelitian. ( Semarang: Universitas Negeri Semarang )

Sumantri,Syarif.2015. Strategi Pembelajaran Teori dan Praktek di Tingkat Pendidikan Dasar. Jakarta: Rajawali Pers. 